\title{
Simulation of tree-ring widths with a model for primary production, carbon allocation, and growth
}

\author{
G. Li ${ }^{1}$, S. P. Harrison ${ }^{1,2}$, I. C. Prentice ${ }^{1,3}$, and D. Falster ${ }^{1}$ \\ ${ }^{1}$ Department of Biological Sciences, Macquarie University, North Ryde, NSW 2109, Australia \\ ${ }^{2}$ School of Archaeology, Geography and Environmental Sciences (SAGES), Reading University, Reading, UK \\ ${ }^{3}$ AXA Chair of Biosphere and Climate Impacts, Grand Challenges in Ecosytem and the Environment, \\ Department of Life Sciences and Grantham Institute for Climate Change, Imperial College London, Ascot, UK
}

Correspondence to: G. Li (guangqi.li@ students.mq.edu.au)

Received: 27 February 2014 - Published in Biogeosciences Discuss.: 4 July 2014

Revised: 20 October 2014 - Accepted: 22 October 2014 - Published: 4 December 2014

\begin{abstract}
We present a simple, generic model of annual tree growth, called " $T$ ". This model accepts input from a first-principles light-use efficiency model (the " $P$ " model). The $P$ model provides values for gross primary production (GPP) per unit of absorbed photosynthetically active radiation (PAR). Absorbed PAR is estimated from the current leaf area. GPP is allocated to foliage, transport tissue, and fineroot production and respiration in such a way as to satisfy well-understood dimensional and functional relationships. Our approach thereby integrates two modelling approaches separately developed in the global carbon-cycle and forestscience literature. The $T$ model can represent both ontogenetic effects (the impact of ageing) and the effects of environmental variations and trends (climate and $\mathrm{CO}_{2}$ ) on growth. Driven by local climate records, the model was applied to simulate ring widths during the period 1958-2006 for multiple trees of Pinus koraiensis from the Changbai Mountains in northeastern China. Each tree was initialised at its actual diameter at the time when local climate records started. The model produces realistic simulations of the interannual variability in ring width for different age cohorts (young, mature, and old). Both the simulations and observations show a significant positive response of tree-ring width to growingseason total photosynthetically active radiation $\left(\mathrm{PAR}_{0}\right)$ and the ratio of actual to potential evapotranspiration $(\alpha)$, and a significant negative response to mean annual temperature (MAT). The slopes of the simulated and observed relationships with $\mathrm{PAR}_{0}$ and $\alpha$ are similar; the negative response to MAT is underestimated by the model. Comparison of simulations with fixed and changing atmospheric $\mathrm{CO}_{2}$ concen-
\end{abstract}

tration shows that $\mathrm{CO}_{2}$ fertilisation over the past 50 years is too small to be distinguished in the ring-width data, given ontogenetic trends and interannual variability in climate.

\section{Introduction}

Forests cover about $30 \%$ of the land surface (Bonan, 2008) and are estimated to contain $861 \pm 66 \mathrm{PgC}$ (Pan et al., 2011). Inventory-based estimates show that forests have been a persistent carbon sink in recent decades, with a gross uptake of $4.0 \pm 0.5 \mathrm{PgC}_{\text {year }}{ }^{-1}$ and a net uptake of $1.1 \pm 0.8 \mathrm{PgC}_{\text {year }}{ }^{-1}$ between 1990 and 2007 (Pan et al., 2011). This is a significant amount in comparison to the amounts of carbon released from fossil fuel burning, cement production, and deforestation $\left(9.5 \pm 0.8 \mathrm{PgC} \mathrm{year}^{-1}\right.$ in 2011 : Ciais et al., 2013), and thus forest growth has a substantial effect on atmospheric $\mathrm{CO}_{2}$ concentration and climate (Shevliakova et al., 2013). However, there is considerable geographic variability in the trends in the carbon sink, as well as the factors controlling regional trends, and uncertainty about how forest growth and carbon sequestration will be affected by climate change, and climate-driven changes in wildfire (Ciais et al., 2013; Moritz et al., 2013). The changing importance of disturbance, and its influence on forest age, is likely to have a significant impact on the ability of forests to act as carbon sinks. It is generally assumed that stand-level productivity stabilises or declines with age (Ryan and Yodar, 1997; Caspersen et al., 2011). However, recent analyses have shown that mass growth rate (and hence 
carbonaccumulation) by individual trees increases continuously with tree size (Stephenson et al., 2014), pointing to a need to understand the relationship between individual and stand-growth rates. Predictions of future changes in the terrestrial carbon cycle (e.g. Friedlingstein and Prentice, 2010) rely on ecosystem models that explicitly represent leaf-level processes, such as photosynthesis, but in most cases do not incorporate the response of individual trees. In models that do consider individual tree growth (e.g. ED: Moorcroft et al., 2001; Medvigy et al., 2012; LPJ-GUESS: Smith et al., 2001; Claesson and Nycander, 2013), little attention has been paid to evaluating the realism of simulated radial growth. Incorporating the response of individual trees to climate and environmental change within such modelling frameworks should help to provide more realistic estimates of the role of forests in the global carbon cycle.

Climate factors, such as temperature and moisture availability during the growing season, are important drivers of tree growth (Harrison et al., 2010). This forms the basis for reconstructing historical climate changes from tree-ring records of annual growth (Fritts, 2012). However, photosynthetically active radiation (PAR) is the principal driver of photosynthesis. Models for primary production that use temperature, not PAR, implicitly rely on the far-from-perfect correlation between temperature and PAR (Wang et al., 2014). PAR can change independently from temperature (through changes in cloudiness affecting PAR or atmospheric circulation changes affecting temperature) and this may help to explain why statistical relationships between tree growth and temperature at some high-latitude and high-elevation sites appear to break down in recent decades (D'Arrigo et al., 2008). $\mathrm{CO}_{2}$ concentration also has an impact on tree growth, although its magnitude is still controversial; trends in tree growth have been attributed to increasing atmospheric $\mathrm{CO}_{2}$ concentration in some studies (Wullschleger et al., 2002; Körner, 2006; Huang et al., 2007; Koutavas, 2013) and not others (Miller, 1986; Luo et al., 2004; Reich et al., 2006). To resolve these apparent conflicts, and to understand treegrowth processes better, it is necessary to analyse the response of tree growth to multiple factors acting simultaneously, including solar radiation, climate, $\mathrm{CO}_{2}$, and ontogenetic stage.

Modelling is needed for this purpose. Empirical models of annual tree-growth and climate variables (temperature and precipitation) have been used to simulate tree radial growth (Fritts, 2012). Process-based bioclimatic models might be preferable, however, because this allows other factors to be taken into account (e.g. the direct impact of $\mathrm{CO}_{2}$ concentration on photosynthesis) and for non-stationarity in the response to specific climate variables. Vaganov et al. (2006) and Rathgeber et al. (2005) have used bioclimatic variables (temperature and soil-moisture availability) chosen to reflect physiological processes to simulate radial tree growth. The MAIDEN model (Misson, 2004; Misson et al., 2004; see also MAIDENiso: Danis et al., 2012) models the pheno- logical and meteorological controls on net primary production (NPP) and explicitly allocates carbon to different carbon pools (including the stem) on a daily basis using phenological stage-dependent rules. Nevertheless, MAIDEN still requires the tuning of several parameters.

Simple equations representing functional and geometric relationships can describe carbon allocation by trees and make it possible to model individual tree growth (Yokozawa and Hara, 1995; Givnish, 1988; Falster et al., 2011; King, 2011). Such models are built on measurable relationships, such as that between stem diameter and height (Thomas, 1996; Ishii et al., 2000; Falster and Westoby, 2005), and crown area and diameter or height (Duursma et al., 2010) that arise because of functional constraints on growth. The pipe model represents the relationship between sapwood area and leaf area (Shinozaki et al., 1964; Yokozawa and Hara, 1995; Mäkelä et al., 2000). The ratio of fine-root mass to foliage area provides the linkage between above- and below-ground tissues (Falster et al., 2011). These functional relationships are expected to be stable through ontogeny, which implies that the fraction of new carbon allocated to different compartments is variable (Lloyd, 1999). In this paper, we combine the two modelling approaches previously developed in the global carbon-cycle (ecophysiology) and forest-science (geometric and carbon allocation) literature to simulate individual tree growth.

\section{Methods}

\subsection{Model structure and derivation}

We use a light-use efficiency model (the $P$ model: Wang et al., 2014), driven by growing-season PAR, climate, and ambient $\mathrm{CO}_{2}$ concentration inputs, to simulate gross primary production (GPP). The simulated GPP is used as input to a species-based carbon allocation and functional geometric tree-growth model (the $T$ model) to simulate individual tree growth (Fig. 1).

\subsubsection{The $P$ model}

The $P$ model is a simple but powerful light-use efficiency and photosynthesis model, which simulates GPP per unit of absorbed PAR from latitude, elevation, temperature, precipitation, and fractional cloud cover (Wang et al., 2014). The climate observations used here are monthly temperature, precipitation, and fractional cloud cover, which are interpolated to a daily time step for subsequent calculations of the variables that determine annual GPP.

Potential annual GPP is the product of the PAR incident on vegetation canopies during the growing season $\left(\mathrm{PAR}_{0}\right)$, with the maximum quantum efficiency of photosynthesis $\left(\Phi_{0}\right)$, the fraction of absorbed PAR (fAPAR), and the effect of photorespiration and substrate limitation at subsaturating $\left[\mathrm{CO}_{2}\right]$, represented as a function of the leaf-internal $\left[\mathrm{CO}_{2}\right]\left(c_{\mathrm{i}}\right)$ and 
the photorespiratory compensation point $\left(\Gamma^{*}\right)$, as shown in Eq. (1).

$\mathrm{GPP}=\Phi_{0}\left(\mathrm{PAR}_{0} \times \mathrm{fAPAR}\right)\left(c_{\mathrm{i}}-\Gamma^{*}\right) /\left(c_{\mathrm{i}}+2 \Gamma^{*}\right)$,

where $\Phi_{0}$ is set to $0.48 \mathrm{~g} \mathrm{C} \mathrm{mol}^{-1}$ photon, based on a quantum efficiency of $0.05 \mathrm{~mol} \mathrm{C} \mathrm{mol}^{-1}$ photon and a leaf absorptance of 0.8 . Daily PAR at the top of the atmosphere is calculated based on solar geometry and is subsequently modified by transmission through the atmosphere, which is dependent on elevation and cloud cover. Annual effective PAR $\left(\mathrm{PAR}_{0}\right)$ is calculated as the annual sum of daily PAR, taking into account the low-temperature inhibition of photosynthesis and growth, using a linear ramp function to downweight PAR on days with temperatures below $10^{\circ} \mathrm{C}$. Days with temperatures below $0{ }^{\circ} \mathrm{C}$ do not contribute to $\mathrm{PAR}_{0}$. See Wang et al. (2014) for details. In this application, we first calculated potential GPP with fAPAR set to 1. fAPAR is not an input to the model, but is calculated implicitly, from the foliage cover simulated by the $T$ model.

Leaf-internal $\left[\mathrm{CO}_{2}\right]$ is obtained from the ambient $\left[\mathrm{CO}_{2}\right]$ via the "least-cost hypothesis" (Wright et al., 2003; Prentice et al., 2014). Wang et al. (2014) provide a continuous prediction of the $c_{\mathrm{i}} / c_{\mathrm{a}}$ ratio as a function of environmental aridity, temperature and elevation based on the following hypothesis:

$c_{\mathrm{i}} / c_{\mathrm{a}}=1 /(1+C \sqrt{ }(\eta \sqrt{ }(D) / K))$,

where $D$ is the cumulative water deficit over a year (proportional to an annual "effective value" of the vapour pressure deficit: VPD), $\eta$ is the dynamic viscosity of water, $K$ is the effective Michaelis-Menten coefficient for Rubisco-limited photosynthesis, and $C$ is a constant. The difference between the annual actual and equilibrium evapotranspiration is used as a proxy for $D$ (see Prentice et al., 2013). $D$ is calculated using the daily interpolated temperature, precipitation, and cloudiness data. Annual actual evapotranspiration is derived from equilibrium evapotranspiration and precipitation using a simple soil-moisture accounting scheme with a daily time step, as described in Gallego-Sala et al. (2010). The temperature dependences of $\eta$ and $K$ follow Prentice et al. (2014). Both $K$ and $\eta$ change steeply with temperature: $K$ changes from $196 \mathrm{ppm}$ at $10^{\circ} \mathrm{C}$ to $1094 \mathrm{ppm}$ at $30^{\circ} \mathrm{C} ; \eta$ decreases from $1.31 \mathrm{mPa}$ s at $10^{\circ} \mathrm{C}$ to only $0.798 \mathrm{mPa}$ at $30^{\circ} \mathrm{C}$.

The temperature dependence of $\Gamma^{*}$ is described by an exponential closely approximating an Arrhenius function (Bernacchi et al., 2003):

$\Gamma^{*}=\Gamma_{25}^{*} \exp (0.0512 \Delta T)$,

where $\Gamma_{25}^{*}$ is the value of $\Gamma^{*}$ at $25^{\circ} \mathrm{C}(4.331 \mathrm{~Pa})$, and $\Delta T$ is the monthly temperature difference from $25^{\circ} \mathrm{C}$.

The $P$ model has been shown to simulate well many of the global patterns of annual and maximum monthly terrestrial GPP by $\mathrm{C}_{3}$ plants. The simulated seasonal cycle of GPP at different latitudes is supported by analyses of $\mathrm{CO}_{2}$ flux measurements (Wang et al., 2014).

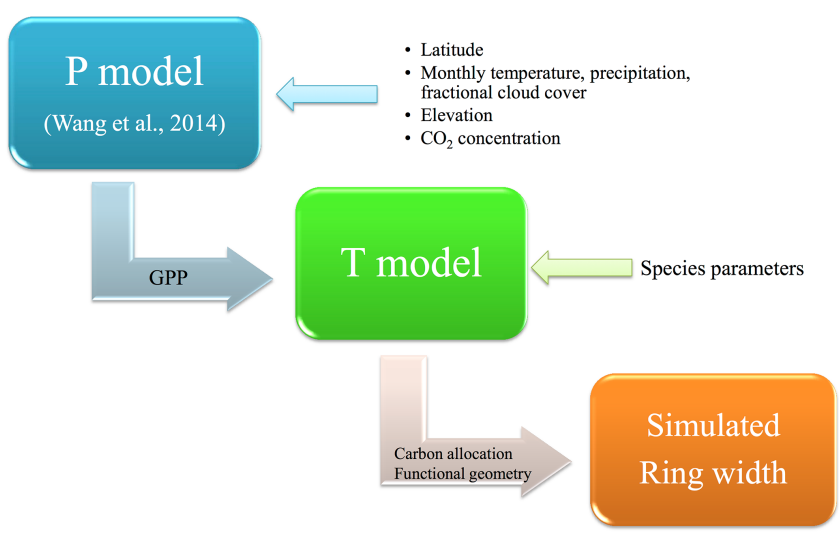

Figure 1. Model application flow. We combined the simple lightuse efficiency and photosynthesis model ( $P$ model) with a carbon allocation and functional geometric tree-growth model to simulate tree growth (e.g. ring width). The inputs to the $P$ model are latitude, elevation, $\left[\mathrm{CO}_{2}\right]$, monthly temperature, precipitation, and fractional cloud cover. Potential gross primary productivity (GPP) simulated by the $P$ model drives the $T$ model. The $T$ model also requires a limited number of species-specific parameter values to be specified.

\subsubsection{The $T$ model}

We assume that potential GPP is the first-order driver of tree growth both at stand and individual level. The $T$ model translates potential GPP, as simulated by the $P$ model into individual tree growth, which depends on foliage cover within the canopy and the respiration of non-green tissues, carbon allocation to different tissues, and relationships between different dimensions of the tree. Although these relationships are often loosely called "allometries", true allometries (power functions) have the undesirable mathematical property for growth modelling that, if the power is greater than 1 , the derivative evaluated at the start of growth is 0 ; if the power is between 0 and 1 , the derivative is infinite. We have therefore avoided the use of power functions, except for geometric relationships, in which they are unambiguously correct.

\section{Functional geometric relationship}

Carbon is allocated to different tissues within the constraint of the basic functional or geometric relationships between different dimensions of the tree.

Asymptotic height-diameter trajectories (Thomas, 1996; Ishii et al., 2000; Falster and Westoby, 2005) are modelled as

$H=H_{\mathrm{m}}\left[1-\exp \left(-a D / H_{\mathrm{m}}\right)\right]$,

where $H$ is the tree height, $D$ is the basal diameter, $H_{\mathrm{m}}$ is the (asymptotic) maximum height, and $a$ is the initial slope of the relationship between height and diameter.

The model also requires the derivative of this relationship:

$\mathrm{d} H / \mathrm{d} D=a \exp \left(-\mathrm{a} D / H_{\mathrm{m}}\right)=a\left(1-H / H_{\mathrm{m}}\right)$. 
The form of the stem is assumed to be paraboloid (Jonson, 1910; Larson, 1963). It can be shown (assuming the pipe model) that this form is uniquely consistent with a uniform vertical distribution of foliage area during early growth; i.e. in the absence of heartwood. Here, the total stem mass $\left(W_{\mathrm{s}}\right)$ is expressed as a function of $D$ and $H$ :

$$
W_{\mathrm{s}}=(\pi / 8) \rho_{\mathrm{s}} D^{2} H,
$$

where $\rho_{\mathrm{s}}$ is the density of the wood, and $(\pi / 8) D^{2} H$ is the volume of a paraboloid stem.

The relationship of diameter increment to stem increment is then given by:

$\mathrm{d} W_{\mathrm{s}} / \mathrm{d} t=(\pi / 8) \rho_{\mathrm{s}}\left[D^{2}(\mathrm{~d} H / \mathrm{d} D)+2 D H\right] \mathrm{d} D / \mathrm{d} t$.

The projected crown area $\left(A_{\mathrm{c}}\right)$ is estimated from $D$ and $H$ using an empirical relationship:

$A_{\mathrm{c}}=(\pi c / 4 a) D H$,

where $c$ is the initial ratio of crown area to stem crosssectional area. This relationship was chosen as an intermediate between previously published expressions that relate $A_{\mathrm{c}}$ either to $D^{2}$ or $H$. It is consistent with reported allometric coefficients typically between 1 and 2 for the relationship between $A_{\mathrm{c}}$ and $D$.

Crown fraction $\left(f_{\mathrm{c}}\right)$ is also derived from $H$ and $D$. As we assumed the stem to be paraboloid, the stem cross-sectional area at height $z$ is

$A_{\mathrm{S}}(z)=A_{\mathrm{S}}(1-z / H)$,

where $A_{\mathrm{S}}$ is the basal area: $A_{\mathrm{s}}=(\pi / 4) D^{2}$. We find the height $\left(z^{*}\right)$ at which the ratio of foliage area $\left(A_{\mathrm{f}}\right)$ to stem area at height $z^{*}\left(A_{\mathrm{s}}\left(z^{*}\right)\right)$ is the same as the initial ratio of crown area to stem cross-sectional area $(c)$. We obtain crown area $\left(A_{\mathrm{c}}\right)$ from:

$A_{\mathrm{c}}=c A_{\mathrm{s}}\left(z^{*}\right)=c A_{\mathrm{s}}\left(1-z^{*} / H\right)$.

Combining this with Eq. (8), we obtain $(\pi c / 4 a) \mathrm{DH}=c A_{\mathrm{S}}$ $(1-z * / H)$, which reduces to

$f_{\mathrm{c}}=\left(1-z^{*} / H\right)=H / \mathrm{a} D$.

The initial slope $(a)$ is, in principle, dependent both on species growth form and ambient conditions, including light availability. Here, it is determined directly from observations.

\section{Carbon allocation}

Actual GPP $(P)$ is obtained from potential GPP $\left(P_{0}\right)$ using Beer's law (Jarvis and Leverenz, 1983):

$P=P_{0} A_{\mathrm{c}}(1-\exp (-k L))$,

where $k$ is the extinction coefficient for PAR, and $L$ is the leaf area index within the crown.
NPP is derived from annual GPP, corrected for foliage respiration (which is set at $10 \%$ of total GPP, an approximation based on the theory developed by Prentice et al., 2014 and Wang et al., 2014) by further deducting growth respiration and the maintenance respiration of sapwood and fine roots. Growth respiration is assumed to be proportional to NPP, following:

$P_{\text {net }}=y\left(P-R_{\mathrm{m}}\right)=y\left(P-W_{\cdot \mathrm{s}} r_{\mathrm{s}}-\zeta \sigma W_{\mathrm{f}} r_{\mathrm{r}}\right)$,

where $P_{\text {net }}$ is NPP, $R_{\mathrm{m}}$ is the maintenance respiration of stem and fine roots, and $y$ is the "yield factor" accounting for growth respiration. Total maintenance respiration of nongreen parts comprises fine-root respiration $\left(\zeta \sigma W_{\mathrm{f}} r_{\mathrm{r}}\right.$, where $\zeta$ is the ratio of fine-root mass to foliage area, $\sigma$ is the specific leaf area, $W_{\mathrm{f}}$ is the mass of carbon in foliage $\left((1 / \sigma) L A_{\mathrm{c}}\right)$, and $r_{\mathrm{r}}$ is the specific respiration rate of fine roots), and stem (sapwood) respiration $\left(W_{\cdot \mathrm{s}} r_{\mathrm{s}}\right.$, where $W_{\text {.s }}$ is the mass of carbon in sapwood, and $r_{\mathrm{s}}$ is the specific respiration rate of sapwood). $W$.s can be estimated from $A_{\mathrm{c}}$ through the pipe model:

$W \cdot \mathrm{s}=L A_{\mathrm{c}} v_{\mathrm{H}} \rho_{\mathrm{s}} H_{\mathrm{f}}$,

where $v_{\mathrm{H}}$ is the Huber value (ratio of sapwood to leaf area; Cruiziat et al., 2002), and $H_{\mathrm{f}}$ is the mean foliage height $H$ $\left(1-f_{\mathrm{c}} / 2\right)$. The constraint that the initial sapwood area must be equal to the stem cross-sectional area leads to the following identity: $L c v_{H}=1$.

NPP is allocated to stem increment $\left(\mathrm{d} W_{\mathrm{s}} / \mathrm{d} t\right)$, foliage increment $\left(\mathrm{d} W_{\mathrm{f}} / \mathrm{d} t\right)$, fine-root increment $\left(\zeta \sigma \mathrm{d} W_{\mathrm{f}} / \mathrm{d} t\right)$, foliage turnover $\left(W_{\mathrm{f}} / \tau_{\mathrm{f}}\right.$, where $\tau_{\mathrm{f}}$ is the turnover time of foliage), and fine-root turnover $\left(\zeta \sigma W_{\mathrm{f}} / \tau_{\mathrm{r}}\right.$, where $\tau_{\mathrm{r}}$ is the turnover time of fine roots). For simplicity, in common with many models, we do not consider allocation to branches and coarse roots separately from allocation to stem:

$P_{\text {net }}=\mathrm{d} W_{\mathrm{s}} / \mathrm{d} t+(1+\zeta \sigma) \mathrm{d} W_{\mathrm{f}} / \mathrm{d} t+\left(1 / \tau_{\mathrm{f}}+\zeta \sigma / \tau_{\mathrm{r}}\right) W_{\mathrm{f}}$.

From Eqs. (13) and (15), the stem increment $\left(\mathrm{d} W_{\mathrm{s}} / \mathrm{d} t\right)$ can now be expressed as:

$$
\begin{aligned}
& \mathrm{d} W_{\mathrm{s}} / \mathrm{d} t=y A_{\mathrm{c}}\left[P_{0}(1-\exp (-k L))-\rho_{\mathrm{s}}\left(1-f_{\mathrm{c}} / 2\right)\right. \\
& \left.H r_{\mathrm{s}} / c-L \zeta r_{\mathrm{r}}\right]-L(\pi c / 4 a)\left[a D\left(1-H / H_{\mathrm{m}}\right)+H\right] \\
& (1 / \sigma+\zeta) \mathrm{d} D / \mathrm{d} t-L A_{\mathrm{c}}\left(1 / \sigma \tau_{\mathrm{f}}+\zeta / \tau_{\mathrm{r}}\right) .
\end{aligned}
$$

The annual increment in $(\mathrm{d} D / \mathrm{d} t)$ and all the other diameterrelated indices are simulated by combining Eqs. (7) and (16).

\subsubsection{Definition of the growing season}

The season over which GPP is accumulated (i.e. the effective growing season) is defined as running from July in the previous year through to the end of June in the current year. This definition is consistent with the fact that photosynthesis peaks around the time of the summer solstice (Bauerle et al., 2012) and that maximum leaf area occurs shortly after this 
Table 1. Parameter description and the derivation of parameter values.

\begin{tabular}{|c|c|c|c|c|}
\hline Parameter & Code & Value & $\begin{array}{l}\text { Uncertainty or } \\
\text { range of value } \\
\text { from literature }\end{array}$ & $\begin{array}{l}\text { Value source: } \\
\text { observation or } \\
\text { published literature }\end{array}$ \\
\hline Initial slope of height-diameter relationship (-) & $a$ & 116 & \pm 4.35 & Observation (Fig. 2) \\
\hline Initial ratio of crown area to stem cross-sectional area (-) & $c$ & 390.43 & \pm 11.84 & Observation (Fig. 2) \\
\hline Maximum tree height (m) & $H_{\mathrm{m}}$ & 25.33 & \pm 0.71 & Observation (Fig. 2) \\
\hline Sapwood density $\left(\mathrm{kg} \mathrm{Cm}^{-3}\right)$ & $\rho_{\mathrm{S}}$ & 200 & \pm 25 & Observation \\
\hline Leaf area index within the crown (-) & $L$ & 1.8 & $1.5-1.96$ & Chen et al. (2004) \\
\hline Specific leaf area $\left(\mathrm{m}^{2} \mathrm{~kg}^{-1} \mathrm{C}\right)$ & $\sigma$ & 14 & $13.22-16.82$ & Huo and Wang (2007) \\
\hline Foliage turnover time (years) & $\tau_{\mathrm{f}}$ & 4 & - & Luo $(1996)$ \\
\hline Fine-root turnover time (years) & $\tau_{\mathrm{r}}$ & 1.04 & - & Shan et al. (1993) \\
\hline PAR extinction coefficient $(-)$ & $k$ & 0.5 & - & Pierce and Running (1988) \\
\hline Yield factor $(-)$ & $y$ & 0.6 & $0.5-0.7$ & Zhang et al. (2009) \\
\hline Ratio of fine-root mass to foliage area $\left(\mathrm{kg} \mathrm{Cm}^{-2}\right)$ & $\zeta$ & 0.17 & - & White et al. (2000) \\
\hline Fine-root specific respiration rate $\left(\right.$ year $\left.^{-1}\right)$ & $r_{\mathrm{r}}$ & 0.913 & - & Yan and Zhao (2007) \\
\hline Sapwood-specific respiration rate $\left(\right.$ year $\left.^{-1}\right)$ & $r_{\mathrm{s}}$ & $\begin{array}{l}0.044(1.4 \\
\mathrm{nmol} \mathrm{mol}\end{array}$ & $\begin{array}{l}0.5-10,20 \\
\mathrm{nmol} \mathrm{mol}^{-1} \mathrm{~s}^{-1}\end{array}$ & Landsberg and Sands (2010) \\
\hline
\end{tabular}

(Rautiainen et al., 2012). Carbon fixed during the later half of the year (July to December) is therefore either stored or allocated for purposes other than foliage expansion. Observations of tree radial growth show that it can occur before leaf-out (in broadleaved trees) or leaf expansion (in needleleaved trees), thus confirming that some part of this growth is based on starch reserves from the previous year (Michelot et al., 2012). This definition of the effective growing season is also supported by analyses of our data, which showed that correlations between simulated and observed tree-ring widths are poorer when the model is driven by GPP from the current calendar year rather than an effective growing season from July through to June.

\subsection{Model application}

\subsubsection{Observations}

We use site-specific information on climate and tree growth from a relatively low-elevation site (ca. $128^{\circ} 02^{\prime} \mathrm{E}, 42^{\circ} 20^{\prime} \mathrm{E}$; $800 \mathrm{~m}$ a.s.1.) in mixed conifer and broadleaf virgin forest in the Changbai Mountains in northeastern China (Bai et al., 2008). This region was chosen because there is no evidence of human influence on the vegetation, and the forests are maintained by natural regeneration. Data on tree height, diameter, and crown area were collected for 400 individual Pinus koraiensis trees from $3520 \mathrm{~m} \times 20 \mathrm{~m}$ sample plots. The 400 trees included all individuals of this species in the 35 plots, representing a complete sampling of the variability in growth. Tree height and diameter were measured directly, and crown area measured as the area of projected ground coverage. Tree-ring cores were obtained from 46 of these individuals in 2007. The selected trees were either from the canopy layer or from natural gaps in the forest, and, in both cases, not overshadowed by nearby indi- viduals in order to minimise the possible effects of competition. An attempt was made to select individuals of different diameters (the diameter at breast height was from 10 to $70 \mathrm{~cm}$ at the time of sampling), broadly corresponding to the range of diameters recorded in the original sampling. The 46 trees were of different ages (ranging from $<50$ to ca. 200 years at the time of sampling in 2006); subsequent analyses show there is little relationship between age and diameter at breast height. Environmental conditions (e.g. soil depth and light availability) were relatively uniform across the sampling plot. Monthly temperature, precipitation, and fractional cloud cover data from 1958 onwards were obtained from the Songjiang meteorological station $\left(128^{\circ} 15^{\prime} \mathrm{E}, 42^{\circ} 32^{\prime} \mathrm{E}\right.$; $591.4 \mathrm{~m}$ a.s.1.), which is representative of the regional climate at low elevations in the Changbai Mountains.

\subsubsection{Derivation of $\boldsymbol{T}$ model parameter values}

$T$ model parameter values were derived from measurements made at the sampling site or from the literature (Table 1). We estimated the initial slope of the height-diameter relationship (a: 116), the initial ratio of crown area to stem cross-sectional area $(c: 390.43)$, and maximum tree height $\left(H_{\mathrm{m}}: 25.33 \mathrm{~m}\right)$ using non-linear regression applied to the diameter at breast height $(D)$, tree height $(H)$, and crown area $\left(A_{\mathrm{c}}\right)$ measurements on all the 400 trees from the sample plots (Fig. 2). We used a value of sapwood density derived from three measurements at the sampling site (Table 1). We used values of leaf area index within the crown $(L)$, specific leaf area $(\sigma)$, foliage turnover time $\left(\tau_{\mathrm{f}}\right)$, and fine-root turnover time $\left(\tau_{\mathrm{r}}\right)$ for Pinus koriensis from field studies conducted in northeastern China (Table 1). No species-specific information was available for the PAR extinction coefficient $(k)$, yield factor $(y)$, ratio of fine-root mass to foliage area $(\zeta)$, fine-root specific respiration rate $\left(r_{\mathrm{r}}\right)$, or sapwood-specific respiration rate $\left(r_{\mathrm{s}}\right)$. 

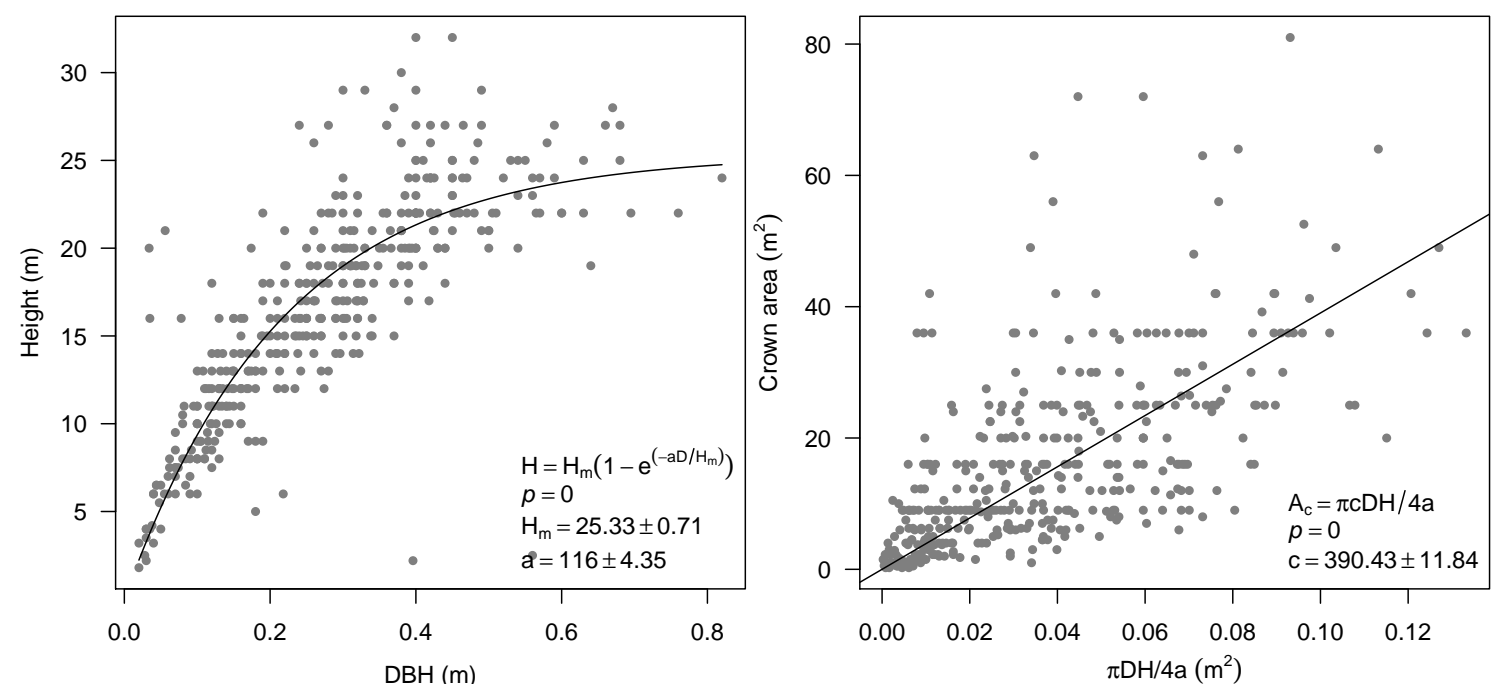

Figure 2. Estimation of parameter values for the application of the $T$ model. Diameter at breast height $(D)$, tree height $(H)$, and crown area $\left(A_{\mathrm{c}}\right)$ of the 400 trees from the sample plots were used for the estimation of the initial slope of the height-diameter relationship $(a)$ and (asymptotic) maximum tree height $\left(H_{\mathrm{m}}\right)$. Relationships among crown area $\left(A_{\mathrm{c}}\right)$, diameter at breast height $(D)$, and height $(H)(\mathrm{Eq} .7)$ are used to estimate the initial ratio of crown area to stem cross-sectional area $(c)$.

We therefore used published values for other species of evergreen needleleaf trees, taken from papers that summarise results from a range of field measurements. Most of the published values for these parameters fall in a relatively narrow range (Table 1). The uncertainty in fine-root specific respiration rate is not given in the original source paper (Yan and Zhao, 2007), but the average value is consistent with other studies (e.g. Zogg et al., 1996). The published values for sapwood-specific respiration rate in pines show considerable variability, ranging from 0.5 to 10 or even $20 \mathrm{nmol} \mathrm{mol}^{-1} \mathrm{~s}^{-1}$ (Landsberg and Sands, 2010). Analyses (see Sect. 3.1) show that the model is sensitive to the specification of sapwood respiration. We therefore selected the final value for this parameter based on calibration of the simulated mean ring width against observations, constrained by the published range of values for sapwood respiration rate.

\subsection{Model application}

We applied the model to simulate the growth of 46 individual Pinus koraiensis trees from the study site between 1958 and 2006. The 46 trees were of different ages (ranging from $<50$ to ca. 200 years at the time of sampling in 2006) and diameters (the diameter was at breast height from 10 to $70 \mathrm{~cm}$ at the time of sampling). Environmental conditions (e.g. soil depth and light availability) were relatively uniform across the sampling plot. The start date for the simulations was determined by the availability of local climate data. Site latitude, elevation, and observed monthly temperature, precipitation, and fractions of cloud cover were used as input for the $P$ model. Each tree was initialised at its actual diameter at 1958, calculated from the measured diameter in 2007 and measured ra- dial growth between 1958 and 2007. The model was initially run with a fixed $\mathrm{CO}_{2}$ concentration of $360 \mathrm{ppm}$. To examine the impact of changing atmospheric $\mathrm{CO}_{2}$ levels on tree growth, we made a second simulation using the observed monthly $\mathrm{CO}_{2}$ concentration between 1958 and 2006 (310 390 ppm: data from the National Oceanic and Atmospheric Administration (NOAA) Earth System Research Laboratory (ESRL) (www.esrl.noaa.gov/gmd/ccgg/trends/)).

\subsection{Statistical methods}

For statistical analyses and comparison with observations, the individual trees were grouped into three cohorts, based on their age in 1958: young (0-49 years); mature (50-99 years); old ( $>100$ years). Individual trees within each cohort exhibit a range of diameters (young: ca. $20-37 \mathrm{~cm}$; mature: 9-59 cm; old: $25-40 \mathrm{~cm}$ ). These differences in size will affect the expression of ontogeny within each cohort. The mean and standard deviation (SD) of year-by-year diameter growth was calculated for each age cohort from the observations and the simulations. The Pearson correlation coefficient and root mean squared error (RMSE) were used to evaluate the degree of agreement between the observations and simulations. We used generalised linear modelling (GLM) (McCullagh, 1984) to analyse the response of tree growth to the major climate factors and age. The GLM approach is helpful for separating the independent influence of individual factors on tree growth, given the inevitable existence of correlations between these factors. 

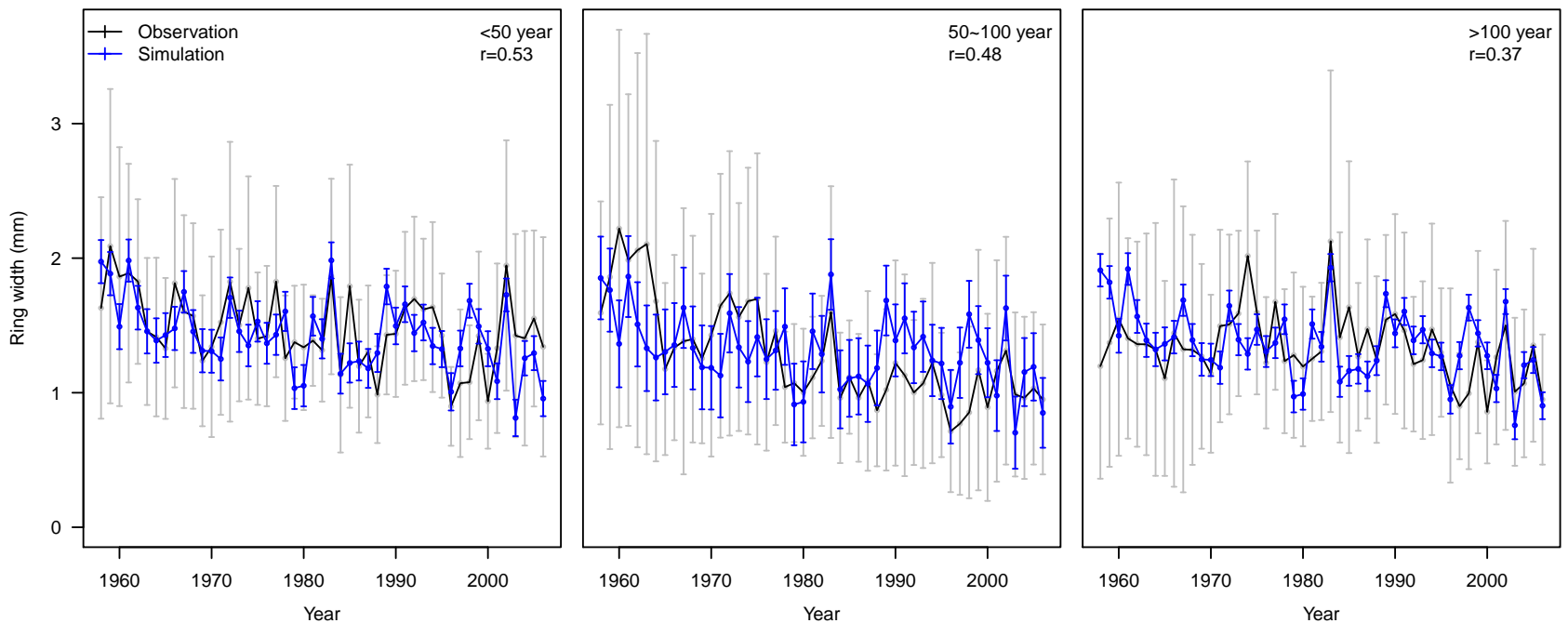

Figure 3. Comparison between simulations and observations for the three age cohorts (young: 0-49 years; mature: 50-99 years; old > 100 years). Each tree was initialised at its actual diameter at 1958, calculated from the measured diameter in 2007, and measured radial growth between 1958 and 2007. The black line is the mean of observations within each age cohort, and grey bars are the standard deviation (SD) of individuals within each age cohort. The blue lines and bars are the mean and standard deviation from the simulations.

\section{Results}

\subsection{Simulated ring width versus observation}

There are only small differences between different age cohorts in the mean simulated ring width, with a mean value of $1.43 \mathrm{~mm}$ for young trees, $1.31 \mathrm{~mm}$ for mature trees, and 1.37 for older trees. These values are comparable to the mean value obtained from the observations $(1.48,1.29$, and $1.34 \mathrm{~mm}$, respectively). However, the general impact of ageing is evident in the decreasing trend in ring widths between 1958 and 2007 within any one cohort (Fig. 3). The slope is stronger in the observations than in the simulations, indicating that the model somewhat underestimates the effects of ontogeny.

There is considerable year-to-year variability in tree growth. The simulated interannual variability (standard deviation) in simulated ring width is similar in all the age cohorts $(0.265 \mathrm{~mm}$ in the young, $0.265 \mathrm{~mm}$ in the mature, and $0.264 \mathrm{~mm}$ in the old trees). This variability is somewhat less than shown by the observations, where interannual variability is $0.274,0.367$, and $0.245 \mathrm{~mm}$, respectively in the young, mature, and old cohorts. The RMSE is 0.263 , 0.332 , and $0.284 \mathrm{~mm}$, respectively for young, mature, and old age cohorts. The correlation between the observed and simulated sequence in each cohort is statistically significant ( $P=0.000,0.001$, and 0.009 , respectively for young, mature, and old age cohorts).

Despite the fact that the model reproduces both the mean ring width and the interannual variability in tree growth reasonably well, the range of ring widths simulated for individual trees within any one cohort is much less than the range seen in the observations. This is to be expected, given that individual tree growth is affected by local factors (e.g. spatial variability in soil moisture) and may also be influenced by ecosystem dynamics (e.g. opening up of the canopy through the death of adjacent trees). These effects are not taken into account in the model.

\subsection{Parameter sensitivity analysis}

To evaluate the sensitivity of the model to specification of individual parameters, we ran a series of simulations in which individual parameter values were increased or decreased by $50 \%$ of their reference value. For each of these simulations, the $T$ model was run for 500 years using constant potential GPP (the mean GPP during the period 1958-2006).

The model simulates a rapid initial increase in ring width, with peak ring widths occurring after ca. 10 years, followed by a gradual and continuous decrease with age (Fig. 4). The model is comparatively insensitive to uncertainties in the specification of fine-root specific respiration rate $\left(r_{\mathrm{r}}\right)$, fineroot turnover time $\left(\tau_{\mathrm{f}}\right)$, and specific leaf area $(\sigma)$, while leaf area index within the crown $(L)$, ratio of fine-root mass to foliage area $(\zeta)$, and fine-root turnover time $\left(\tau_{\mathrm{r}}\right)$ only have a moderate effect on the simulated amplitude of ring width. The largest impacts on the amplitude of the simulated ring width are from the initial slope of the height-diameter relationship (a), initial ratio of crown area to stem crosssectional area $(c)$, and sapwood density $\left(\rho_{\mathrm{s}}\right)$. Maximum tree height $\left(H_{\mathrm{m}}\right)$ and sapwood-specific respiration rate $\left(r_{\mathrm{s}}\right)$ have the greatest influence on the shape of the simulated ageing curve. These two parameters also have a large impact on the amplitude of the growth of old trees. The parameter 


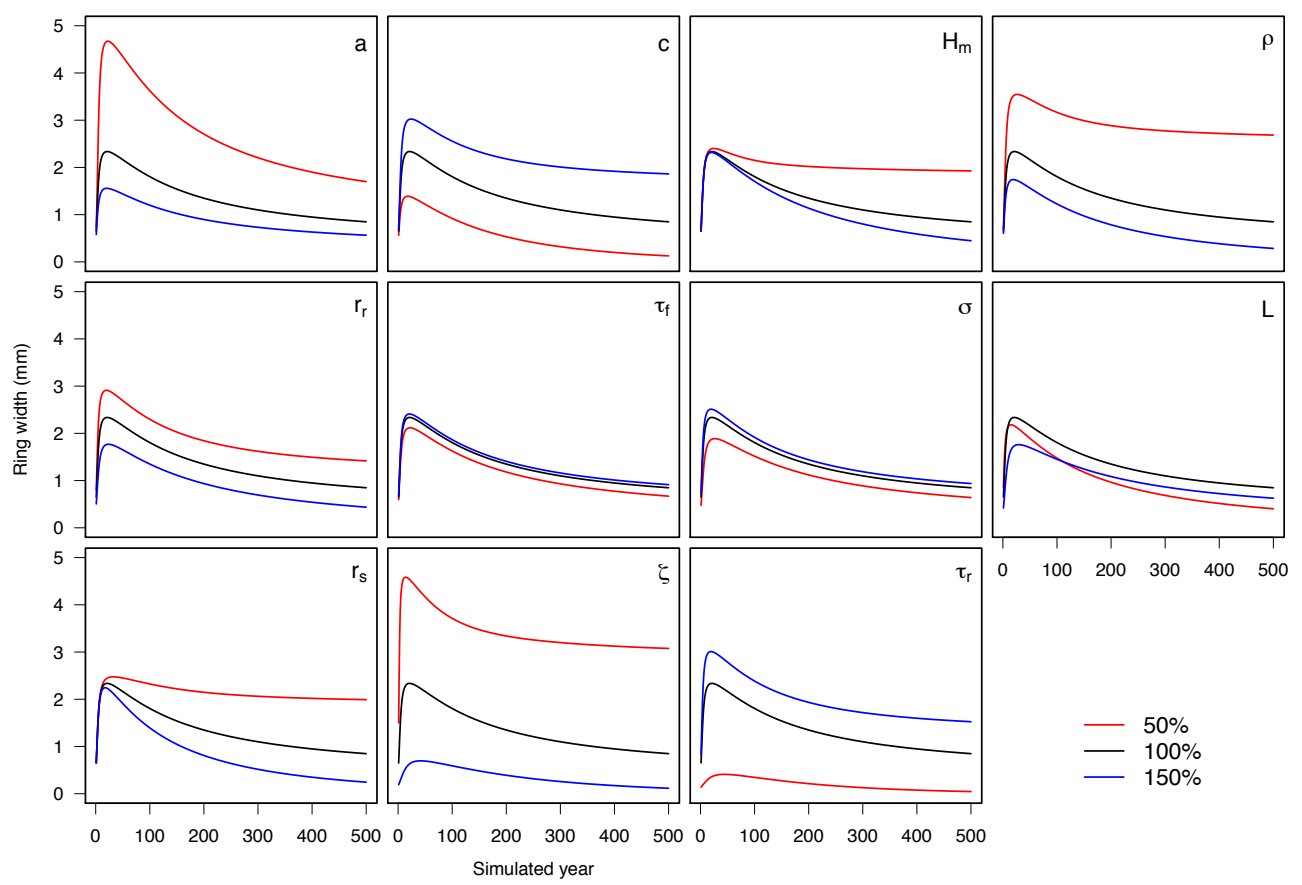

Figure 4. Parameter sensitivity analyses for the $T$ model. A constant input of gross primary productivity (GPP) (mean during the period 1958-2006) was used to drive the $T$ model to simulate tree growth for 500 years following establishment. The black line was obtained with the reference value of each parameter. The effects of an increase (150\% of reference value; blue line) and a decrease (50\% of reference value; red line) are also shown.

Table 2. GLM analysis of tree-growth response to the climatic factors and age, based on simulations and observations. The dependent variable is mean ring width series (1958-2006) for each age cohort (young, mature, and old). The independent variables are the growing-season total annual photosynthetically active radiation $\left(\mathrm{PAR}_{0}\right)$, mean annual temperature (MAT), and the ratio of actual to potential evapotranspiration $(\alpha)$, with age cohort treated as a factor.

\begin{tabular}{llccrr}
\hline & & $\begin{array}{c}\text { Intercept } \\
(\mathrm{mm})\end{array}$ & $\begin{array}{c}\mathrm{PAR}_{0} \\
\left(\mathrm{~mm}\left(\mathrm{kmol} \mathrm{photon} \mathrm{m}^{-2}\right)^{-1}\right)\end{array}$ & $\begin{array}{c}\text { MAT } \\
\left(\mathrm{mm}^{\circ} \mathrm{C}^{-1}\right)\end{array}$ & \multicolumn{1}{c}{$\begin{array}{c}\alpha \\
(\mathrm{mm})\end{array}$} \\
\hline \multirow{3}{*}{ Observation } & Estimation & -3.123 & 0.625 & -0.180 & 0.702 \\
& Error & \pm 0.784 & \pm 0.093 & \pm 0.042 & \pm 0.301 \\
& $p$ value & 0.004 & 0.000 & 0.000 & 0.021 \\
\hline \multirow{3}{*}{ Simulation } & Estimation & -7.139 & 1.056 & -0.078 & 1.142 \\
& Error & \pm 0.169 & \pm 0.020 & \pm 0.009 & \pm 0.065 \\
& $p$ value & 0.000 & 0.000 & 0.000 & 0.000 \\
\hline
\end{tabular}

values for a, c, $\mathrm{H}_{\mathrm{m}}$, and $\rho_{\mathrm{s}}$ are derived from observations, with uncertainties much less than $50 \%$ (Fig. 2). Thus, the sensitivity of the model to these parameters is not important. However, model sensitivity to sapwood respiration $\left(r_{\mathrm{s}}\right)$, both in terms of the shape of the ageing curve and the amplitude, is of greater concern, given the large range of values in the literature. Although some part of the uncertainty in the specification of sapwood respiration may be due to differences between species, the difficulty of measuring this trait accurately also contributes to the problem. For the final model, we tuned $r_{\mathrm{s}}$ against the ring-width observations. The best match with the observations was obtained with a value of $1.4 \mathrm{nmol} \mathrm{mol}^{-1} \mathrm{~s}^{-1}$, which is within the range of published values for pines (see summary in Landsberg and Sands, 2010). $r_{\mathrm{s}}$ is the only parameter that was tuned.

\subsection{Controls on tree growth}

The GLM analysis revealed a strong positive relationship between $\mathrm{PAR}_{0}$ and tree growth, while moisture stress (as measured by $\alpha$, an estimate of the ratio of actual to potential evapotranspiration) was shown to have a less steep but still positive effect (Fig. 5 and Table 2). The observed partial relationship between mean annual temperature and tree growth is negative. The Changbai Mountains are at the southern end of 

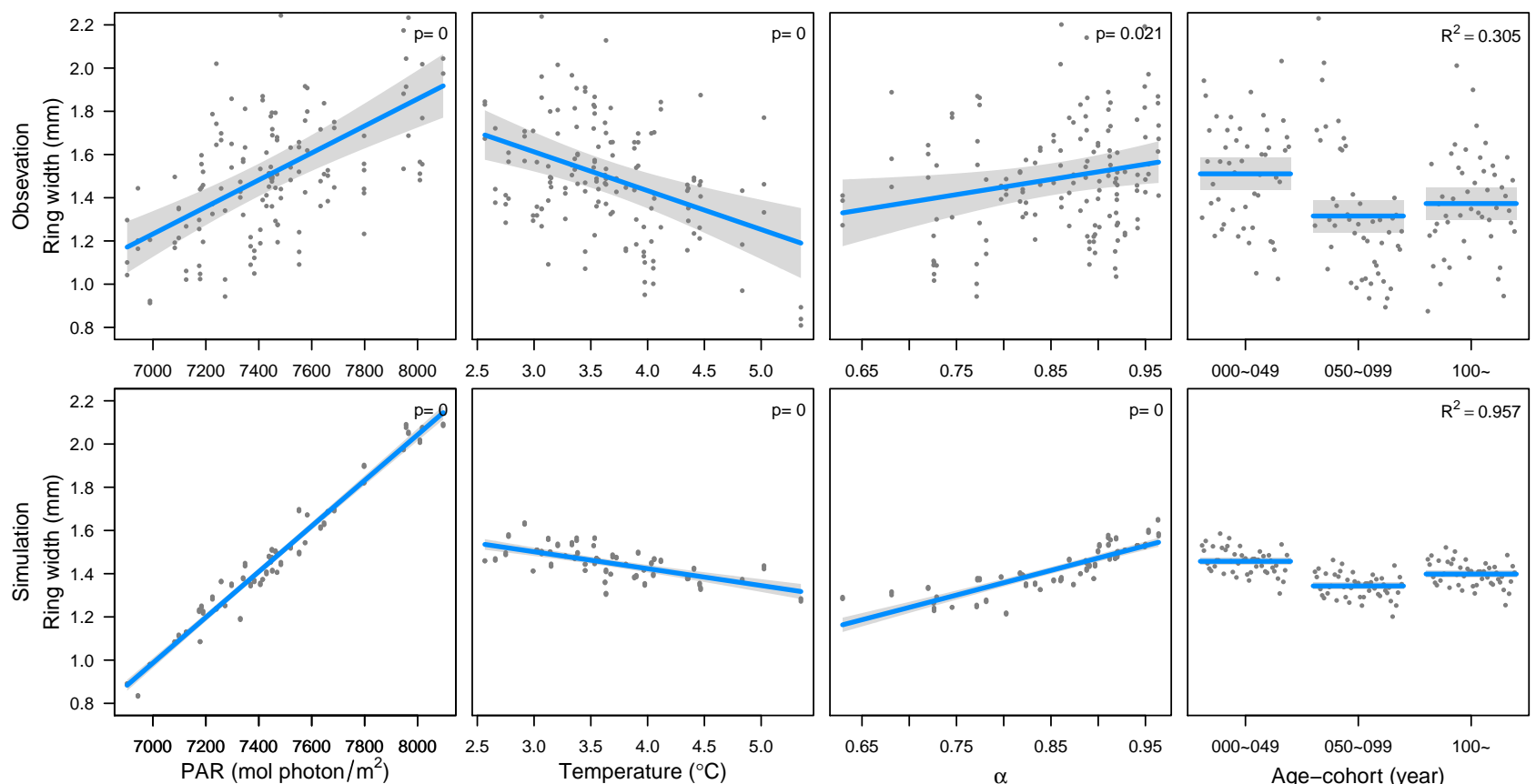

Figure 5. Tree-growth response to climate and tree age: partial residual plots based on the GLM analysis (Table 2), obtained using the visreg package in $R$, are shown.

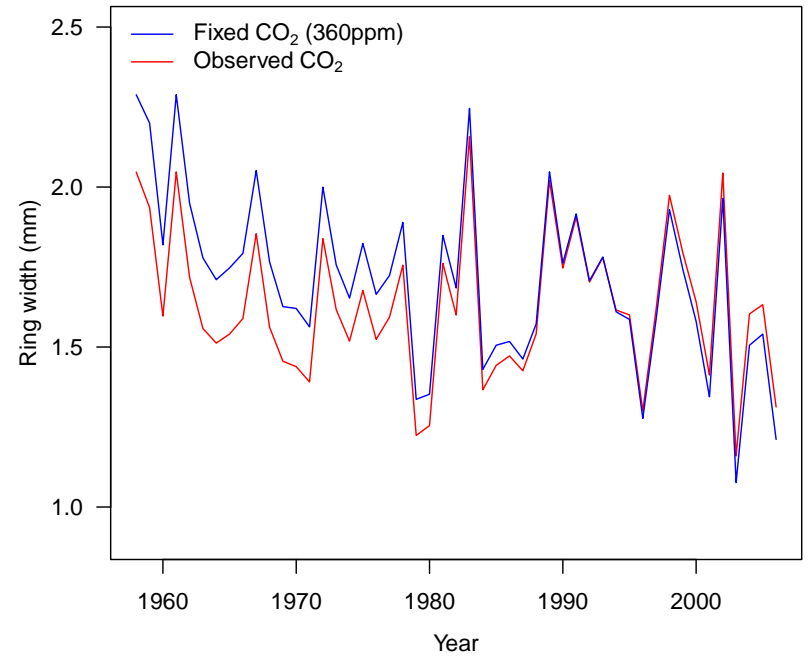

Figure 6. $\mathrm{CO}_{2}$ effect on tree growth. Two runs, one with a fixed $360 \mathrm{ppm}\left[\mathrm{CO}_{2}\right]$ (blue line), the other with observed monthly $\left[\mathrm{CO}_{2}\right]$ (red line), are compared to show the simulated effect of $\left[\mathrm{CO}_{2}\right]$ on tree growth during the period 1958-2006.

the distribution of Pinus koraiensis in China, which makes it plausible that tree growth would be inhibited during warmer years.

The model reproduces these observed relationships between climate factors and tree growth. The slope of the observed positive relationship with $\alpha$ is statistically indistinguishable from the modelled slope, but the observed positive relationship with $\mathrm{PAR}_{0}$ is weaker, and the negative correlation with mean annual temperature is stronger in the observations than in the simulations. These differences between observations and simulations could reflect the influence of an additional climate control, related to both $\mathrm{PAR}_{0}$ and temperature (e.g. cloud cover). The difference between observed and simulated effects of temperature may also be because, although simulated growth is inhibited by low temperatures (through the computation of $\mathrm{PAR}_{0}$ ), the current model does not include any mechanism for inhibition due to heat stress at high air and leaf temperatures.

The GLM analysis also showed that age, as represented by the three age cohorts, has an impact on ring width: young trees have greater ring widths than mature trees, while old trees have somewhat greater ring widths than mature trees. This pattern is seen in both the observations and simulations, although the differences between the young and mature cohorts are slightly greater in the observations.

The overall similarity in the observed and simulated relationships between growth rates and environmental factors confirms that the $T$ model performs realistically. The observed relationships are considerably noisier than the simulated relationships (Fig. 5, Table 2), reflecting the fact that growth rates are affected by small-scale variability in environmental conditions, as well as time-varying competition for light. 


\subsection{Simulated $\mathrm{CO}_{2}$ effect on tree growth}

Elevated levels of $\mathrm{CO}_{2}$ are expected to have a positive impact on tree growth (Hyvönen et al., 2007; Donohue et al., 2013; Hickler et al., 2008; Boucher et al., 2014). This positive response to $\left[\mathrm{CO}_{2}\right]$ is seen in the comparison of the fixed $\left[\mathrm{CO}_{2}\right]$ and real $\left[\mathrm{CO}_{2}\right]$ simulations (Fig. 6). In the first part of the simulation, prior to 1980 , the actual $\left[\mathrm{CO}_{2}\right]$ is lower than the level of $360 \mathrm{ppm}$ used in the fixed $\left[\mathrm{CO}_{2}\right]$ experiment. This results in lower growth rates. The $50 \mathrm{ppm}$ difference between the two experiments at the beginning of the simulation results in a difference in ring width of $0.242 \mathrm{~mm}$. After 1980, when the actual $\left[\mathrm{CO}_{2}\right]$ was higher than $360 \mathrm{ppm}$, the tree growth in the simulation with realistic $\left[\mathrm{CO}_{2}\right]$ is enhanced. The $30 \mathrm{ppm}$ difference at the end of the simulation results in a difference in ring width of $0.101 \mathrm{~mm}$. Overall, the change in $\left[\mathrm{CO}_{2}\right]$ between 1958 and 2006 results in a positive enhancement of tree growth of ca. $0.343 \mathrm{~mm} \mathrm{yr}^{-1}$. However, this difference is very small compared to the impact of ageing ( $>1 \mathrm{~mm}$ from observations) or to the differences resulting from the interannual variability of climate $(1.212 \mathrm{~mm})$ on tree growth.

\section{Discussion}

We have shown that radial growth (ring width) can be realistically simulated by coupling a simple generic model of GPP with a model of carbon allocation and functional geometric tree growth with species-specific values. The model is responsive to changes in climate variables, and can account for the impact of changing $\mathrm{CO}_{2}$ and ontogeny on tree growth. Although several models draw on basic physiological and/or geometric constraints in order to simulate tree-ring indices (Fritts, 2012; Vaganov et al., 2006; Rathgeber et al., 2005; Misson, 2004), and indeed the two approaches have been combined to simulate between-site differences in ecosystem productivity and tree growth (Härkönen et al., 2010, 2013), this is the first time, to our knowledge, that the two approaches have been combined to yield an explicit treatment of individual tree-growth processes, tested against an extensive ring-width data set.

Our simulations suggest that, after a brief but rapid increase for young plants, there is a general and continuous decrease in radial growth with age (Fig. 4). This pattern is apparent in individual tree-ring series, and is evident in the decreasing trend in ring widths shown when the series are grouped into age cohorts (Fig. 3). It is a necessary consequence of the geometric relationship between the stem diameter increment and cross-sectional area; more biomass is required to produce the same increase in diameter in thicker, taller trees than thinner, shorter ones. However, we find that ring widths in old trees in our study region are consistently wider than those in mature trees, and this property is reproduced in the simulations (Fig. 5). This situation arises because the old trees are, on average, smaller than the mature trees at the start of the simulation (in 1958). Thus, while the difference between average ring widths in the mature and old cohorts conforms to the geometric relationship between stem diameter increment and cross-sectional area, it is a response that also reflects differences in the history of tree growth at this site, which determined the initial size of the trees in 1958. Lack of climate data prior to 1958 or detailed information about stand dynamics precludes diagnosis of the cause of the growth history differences between mature and old trees.

Studies attempting to isolate the impact of climate variability on tree growth, including attempts to reconstruct historical climate changes using tree-ring series, often describe the impact of ageing as a negative exponential curve (Fritts, 2012). However, our analyses suggest that this is not a good representation of the actual effect of ageing on tree growth, and would result in the masking of the impact of climate-induced variability in mature and old trees. The simulated NPP of individual trees always increases with size (or age). This is consistent with the observation that carbon sequestration increases continuously with individual tree size (Stephenson et al., 2014).

We have shown that total PAR during the growing season is positively correlated with tree growth at this site. This is not surprising given that PAR is the primary driver of photosynthetic carbon fixation. However, none of the empirical or semi-empirical models of tree growth uses PAR directly as a predictor variable; most use some measure of seasonal or annual temperature as a surrogate. PAR is determined by latitude and cloudiness. Although temperature varies with latitude and cloudiness, it is also influenced by other factors, including heat advection. Temperature changes can impact the length of the growing season, and hence have an impact on total growing-season PAR, but this is a trivial effect over recent decades. In fact, we show that mean annual temperature is negatively correlated with tree growth at this site. Given this decoupling, and the potential that longer-term changes in cloudiness will not necessarily be correlated with changes in temperature (Charman et al., 2013), we strongly advocate the use of growing-season PAR for empirical modelling, as well as in process-based modelling.

We found no age-related sensitivity to interannual variability in climate; the interannual variability in ring width is virtually identical between age cohorts. The strength of the relationship with individual climate variables is also similar between the three age cohorts. It is generally assumed that juvenile and old trees are at greater risk of mortality from environmental stress than mature trees are (e.g. Lines et al., 2010; McDowell et al., 2008). This may be true in the case of extreme events, such as wildfires, windthrow, or pest attacks. Our results suggest that, although climate variability has an important effect on tree growth, it is not an important influence on mortality.

We have assumed that the period contributing to growth (i.e. the effective growing season) in any year includes carbon stores generated during the second half of the previous 
year. The total foliage area determines the radial area of the stem, and, once this is achieved, NPP is allocated either to fine-root production or stored as carbohydrate for use in stem growth in the early part of the subsequent year. This is consistent with observations that radial growth begins before leaf-out (Michelot et al., 2012) and that maximum leaf area is generally achieved by mid-summer (Rautiainen et al., 2012). The MAIDEN model also allows tree growth to be influenced by a fixed contribution from the previous year's growth (Misson, 2004). Defining the effective growing season as being only the current growth year had no impact on the influence of climate on ring widths, or the shape of the ageing curve. It did, however, produce a considerably lower correlation between simulated and observed interannual variability in growth. Since tree-ring width reflects the integrated climate over the "effective growing season", reconstructions of climate variables reflect conditions during that season, not only during the current calendar year.

The high degree of autocorrelation present in tree-ring series is often seen as a problem requiring pretreatment of the series in order to derive realistic reconstructions of climate variables (e.g. Cook et al., 2012; Anchukaitis et al., 2013; Wiles et al., 2014). However, spatial or temporal autocorrelation is a reflection of the causal mechanism underpinning the observed patterning. Here, we postulate that the mechanism that gives rise to the temporal autocorrelation in tree-ring series is the existence of carbon reserves that are created in one year and fuel early growth in the next. If a large reserve of carbon is created in the second half of the growing season, because of favourable conditions, this will offset poor conditions in the following year. However, large reserves may not be necessary if conditions during the subsequent growing year are very favourable. The fact that the relative influence of one year on the next can vary explains why the measured autocorrelation strength in a given tree-ring series varies through time.

The $T$ model is sensitive to the values adopted for some parameters, specifically the initial slope of the heightdiameter relationship $(a)$, the initial ratio of crown area to stem cross-sectional area $(c)$, maximum tree height $\left(H_{\mathrm{m}}\right)$, sapwood density $\left(\rho_{\mathrm{s}}\right)$, sapwood-specific respiration rate $\left(r_{\mathrm{s}}\right)$, leaf area index within the crown $(L)$, ratio of fine-root mass to foliage area $(\zeta)$, and fine-root turnover time $\left(\tau_{\mathrm{r}}\right)$. Several of these parameters are easily derived from observations (e.g. $a, c, H_{\mathrm{m}}, \rho_{\mathrm{s}}$, and $\left.L\right)$ and, provided that sufficient site-based observations are available, they should not pose a problem for applications of the model. However, the model is also sensitive to less easily measured parameters, including sapwood respiration, root respiration, and the ratio of fine roots to leaves. Estimates of values for root respiration and root mass to foliage area in the literature do not show substantial differences, and we therefore used an average value to parameterise our model. This approach could be used for other applications. We parameterised fine-root turnover rates based on observations on Pinus koraiensis from Changbai. While this obviated the need for tuning in the current application, lack of data on fine-root turnover rates in other regions (or for other species) could pose problems for future applications of the model. The model is also highly sensitive to the parameter value used for sapwood respiration, and the range of reported values is large (Table 1). Because of this, we derived a value for sapwood respiration by tuning the model to obtain a good representation of average ring width. This is the only parameter that requires tuning in the current version of the $T$ model. Although sapwood respiration is difficult to measure, it would certainly be better if more measurements of sapwood respiration were available, as this would remove the need for model tuning.

Our modelling approach integrates the influence of climate, $\left[\mathrm{CO}_{2}\right]$, and ontogeny on individual tree growth. Such a model is useful to explore the response of tree growth to potential future changes in climate, and the impact of changes in tree growth on carbon sequestration. We also envisage that it could also be used to investigate the impact of past climate changes on tree growth. Reconstructions of temperature changes beyond the recent observational period, used as a baseline for the detection of anthropogenic influences on the climate system, are largely derived from statistical reconstructions based on tree-ring series (Jones et al., 1998; Esper et al., 2002; Hegerl et al., 2006; Mann et al., 2008; Ahmed et al., 2013). However, as we show here, temperature is neither the only nor the most important influence on tree growth. This may help to explain why correlations between ring widths and climate at individual sites appear to have broken down in recent decades (the so-called "divergence problem"; D' Arrigo et al., 2008). The availability of a robust model to investigate tree growth could help to provide better reconstructions of past climate changes (see Boucher et al., 2014, for example), as well as more plausible projections of the response of tree growth to continuing climate change in the future.

Acknowledgements. We thank Wang Han for assistance with the $P$ model. G. $\mathrm{Li}$ is supported by an International Postgraduate Research Scholarship at Macquarie University. The work is a contribution to the AXA Chair programme on Biosphere and Climate Impacts and the Imperial College initiative Grand Challenges in Ecosystems and the Environment.

Edited by: U. Seibt

\section{References}

Ahmed, M., Anchukaitis, K. J., Asrat, A., Borgaonkar, H. P., Braida, M., Buckley, B. M., Büntgen, U., Chase, B. M., Christie, D. A., and Cook, E. R.: Continental-scale temperature variability during the past two millennia, Nat. Geosci., 6, 339-346, 2013.

Anchukaitis, K. J., D’Arrigo, R. D., Andreu-Hayles, L., Frank, D., Verstege, A., Curtis, A., Buckley, B. M., Jacoby, G. C., 
and Cook, E. R. Tree-Ring-Reconstructed Summer Temperatures from Northwestern North America during the Last Nine Centuries. J. Clim., 26, 3001-3012, 2013.

Bai, F., Sang, W., Li, G., Liu, R., Chen, L., and Wang, K.: Longterm protection effects of national reserve to forest vegetation in 4 decades: biodiversity change analysis of major forest types in Changbai Mountain Nature Reserve, China, Sci. China Ser. C, 51, 948-958, 2008.

Bauerle, W. L., Oren, R., Way, D. A., Qian, S. S., Stoy, P. C., Thornton, P. E., Bowden, J. D., Hoffman, F. M., and Reynolds, R. F.: Photoperiodic regulation of the seasonal pattern of photosynthetic capacity and the implications for carbon cycling, P. Natl. Acad. Sci., 109, 8612-8617, 2012.

Bernacchi, C., Pimentel, C., and Long, S.: In vivo temperature response functions of parameters required to model RuBP-limited photosynthesis, Plant Cell Environ., 26, 1419-1430, 2003.

Bonan, G. B.: Forests and climate change: forcings, feedbacks, and the climate benefits of forests, Science, 320, 1444-1449, 2008.

Boucher, É., Guiot, J., Hatté, C., Daux, V., Danis, P.-A., and Dussouillez, P.: An inverse modeling approach for tree-ring-based climate reconstructions under changing atmospheric $\mathrm{CO}_{2}$ concentrations, Biogeosciences, 11, 3245-3258, doi:10.5194/bg-113245-2014, 2014.

Caspersen, J. P., Vanderwel, M. C., Cole, W. G., and Purves, D. W.: How stand productivity results from size-and competitiondependent growth and mortality, PLoS One, 6, e28660, 2011.

Charman, D. J., Beilman, D. W., Blaauw, M., Booth, R. K., Brewer, S., Chambers, F. M., Christen, J. A. Gallego-Sala, A., Harrison, S. P., Hughes, P. D. M., Jackson, S. T., Korhola, A., Mauquoy, D., Mitchell, F. J. G., Prentice, I. C., van der Linden, M., de Vleeschouwer, F., Yu, Z. C., Alm, J., Bauer, I. E., Corish, Y. M. C., Garneau, M., Hohl, V., Huang, Y., Karofeld, E., Le Roux, G., Moschen, R., Nichols, J. E., Nieminen, T., McDonald, G. M., Phadtare, N. R., Rausch, N., Shotyk, W., Sillasoo, U., Swindles, G. T., Tuittila, E. S., Ukonmaanaho, L., Väliranta, M., van Bellen, S., van Geel, B., Vitt, D. H., and Zhao, Y.: Climate-driven changes in peatland carbon accumulation during the last millennium, Biogeosciences, 10, 929-944, doi:10.5194/bg-10-9292013, 2013.

Chen, G., Dai, L., and Zhou, L.: Structure of stand and canopy characteristics of disturbed communities of broadleaved Pinus koraiensis forest in Changbai Mountain [J], Chin. J. Ecol., 23, 116-120, 2004.

Ciais, P., Sabine, C., Bala, G., Bopp, L., Brovkin, V., Canadell, J., Chhabra, A., DeFries, R., Galloway, J., Heimann, M., Jones, C., Quéré, C. L., Myneni, R. B., Piao, S., and Thornton, P.: Carbon and Other Biogeochemical Cycles, in: Climate Change 2013: The Physical Science Basis. Contribution of Working Group I to the Fifth Assessment Report of the Intergovernmental Panel on Climate Change, edited by: Stocker, T. F., Qin, D., Plattner, G.K., Tignor, M., Allen, S. K., Boschung, J., Nauels, A., Xia, Y., Bex, V., and Midgley, P. M., Cambridge University Press, Cambridge, UK and New York, NY, USA, 2013.

Claesson, J. and Nycander, J.: Combined effect of global warming and increased $\mathrm{CO}_{2}$-concentration on vegetation growth in waterlimited conditions, Ecol. Model., 256, 23-30, 2013.

Cook, E. R., Krusic, P. J., Anchukaitis, K. J., Buckley, B. M., Nakatsuka, T., and Sano, M.: Tree-ring reconstructed summer tempera- ture anomalies for temperate East Asia since 800 CE, Clim. Dyn., 41, 2957-2972, 2012.

Cruiziat, P., Cochard, H., and Améglio, T.: Hydraulic architecture of trees: main concepts and results, Ann. For. Sci., 59, 723$752,2002$.

Danis, P.-A., Hatté, C., Misson, L., and Guiot, J.: MAIDENiso: a multiproxy biophysical model of tree-ring width and oxygen and carbon isotopes, Can. J. Forest Res., 42, 1697-1713, 2012.

D'Arrigo, R., Wilson, R., Liepert, B., and Cherubini, P.: On the 'divergence problem' in northern forests: a review of the tree-ring evidence and possible causes, Global Planet. Change, 60, 289305, 2008.

Donohue, R. J., Roderick, M. L., McVicar, T. R., and Farquhar, G. D.: Impact of $\mathrm{CO}_{2}$ fertilization on maximum foliage cover across the globe's warm, arid environments, Geophys. Res. Lett., 40, 3031-3035, 2013.

Duursma, R. A., Mäkelä, A., Reid, D. E., Jokela, E. J., Porté, A. J., and Roberts, S. D.: Self-shading affects allometric scaling in trees, Funct. Ecol., 24, 723-730, 2010.

Esper, J., Cook, E. R., and Schweingruber, F. H.: Low-frequency signals in long tree-ring chronologies for reconstructing past temperature variability, Science, 295, 2250-2253, 2002.

Falster, D. S. and Westoby, M.: Tradeoffs between height growth rate, stem persistence and maximum height among plant species in a post-fire succession, Oikos, 111, 57-66, 2005.

Falster, D. S., Brännström, ̊̊., Dieckmann, U., and Westoby, M.: Influence of four major plant traits on average height, leaf-area cover, net primary productivity, and biomass density in singlespecies forests: a theoretical investigation, J. Ecol., 99, 148-164, 2011.

Friedlingstein, P. and Prentice, I.: Carbon-climate feedbacks: a review of model and observation based estimates, Curr. Opin. Environ. Sustain., 2, 251-257, 2010.

Fritts, H. C.: Tree rings and climate, Academic Press, London, 2012.

Gallego-Sala, A. V., Clark, J. M., House, J. I., Orr, H. G., Prentice, I. P., Smith, P., Farewell, T., and Chapman, S. J.: Bioclimatic envelope model of climate change impacts on blanket peatland distribution in Great Britain, Clim. Res., 45, 151-162, 2010.

Givnish, T. J.: Adaptation to sun and shade: a whole-plant perspective, Funct. Plant Biol., 15, 63-92, 1988.

Härkönen, S., Pulkkinen, M., Duursma, R., and Mäkelä, A.: Estimating annual GPP, NPP and stem growth in Finland using summary models, Forest. Ecol. Manag., 259, 524-533, 2010

Härkönen, S., Tokola, T., Packalén, P., Korhonen, L., and Mäkelä, A.: Predicting forest growth based on airborne light detection and ranging data, climate data, and a simplified process-based model, Can. J. For. Res., 43, 364-375, 2013.

Harrison, S. P., Prentice, I. C., Barboni, D., Kohfeld, K. E., Ni, J., and Sutra, J. P.: Ecophysiological and bioclimatic foundations for a global plant functional classification, J. Veg. Sci.I, 21, 300-317, 2010.

Hegerl, G. C., Crowley, T. J., Hyde, W. T., and Frame, D. J.: Climate sensitivity constrained by temperature reconstructions over the past seven centuries, Nature, 440, 1029-1032, 2006.

Hickler, T., Smith, B., Prentice, I. C., Mjöfors, K., Miller, P., Arneth, A., and Sykes, M. T.: $\mathrm{CO}_{2}$ fertilization in temperate FACE experiments not representative of boreal and tropical forests, Global Change Biol., 14, 1531-1542, 2008. 
Huang, J., Bergeron, Y., Denneler, B., Berninger, F., and Tardif, J.: Response of forest trees to increased atmospheric $\mathrm{CO}_{2}$, Crit. Rev. Plant Sci., 26, 265-283, 2007.

Huo, H. and Wang, C.: Effects of canopy position and leaf age on photosynthesis and transpiration of Pinus koraiensis, Chin. J. Appl. Ecol., 18, 1181-1186, 2007.

Hyvönen, R., Ågren, G. I., Linder, S., Persson, T., Cotrufo, M. F., Ekblad, A., Freeman, M., Grelle, A., Janssens, I. A., and Jarvis, P. G.: The likely impact of elevated $\left[\mathrm{CO}_{2}\right]$, nitrogen deposition, increased temperature and management on carbon sequestration in temperate and boreal forest ecosystems: a literature review, New Phytol., 173, 463-480, 2007.

Ishii, H., Reynolds, J. H., Ford, E. D., and Shaw, D. C.: Height growth and vertical development of an old-growth PseudotsugaTsuga forest in southwestern Washington State, USA, Can. J. Forest Res., 30, 17-24, 2000.

Jarvis, P. G. and Leverenz, J. W.: Productivity of temperate, deciduous and evergreen forests, in: Physiological plant ecology IV, Springer, Berlin Heidelberg, 233-280, 1983.

Jones, P. D., Briffa, K. R., Barnett, T. P., and Tett, S. F. B.: Highresolution palaeoclimatic records for the last millennium: interpretation, integration and comparison with General Circulation Model control-run temperatures, Holocene, 8, 455-471, 1998.

Jonson, T.: Taxatoriska undersokningar am skogstradens form: (1) granens stamform, Skogsvardfor, Tidskrift, 8, 285-328, 1910.

King, D. A.: Size-related changes in tree proportions and their potential influence on the course of height growth, in: Size-and agerelated changes in tree structure and function, Springer, Netherlands, 165-191, 2011.

Körner, C.: Plant $\mathrm{CO}_{2}$ responses: an issue of definition, time and resource supply, New Phytol., 172, 393-411, 2006.

Koutavas, A.: $\mathrm{CO}_{2}$ fertilization and enhanced drought resistance in Greek firs from Cephalonia Island, Greece, Global Change Biol., 19, 529-539, 2013.

Landsberg, J. J. and Sands, P.: Physiological ecology of forest production: principles, processes and models, Academic Press, 2010.

Larson, P. R.: Stem form development of forest trees, For. Sci., Monograph, 5, 1-42, 1963.

Lines, E. R., Coomes, D. A., and Purves, D. W.: Influences of forest structure, climate and species composition on tree mortality across the eastern US, PLoS One, 5, e13212, doi:10.1371/journal.pone.0013212, 2010.

Lloyd, J.: The $\mathrm{CO}_{2}$ dependence of photosynthesis, plant growth responses to elevated $\mathrm{CO}_{2}$ concentrations and their interaction with soil nutrient status, II. Temperate and boreal forest productivity and the combined effects of increasing $\mathrm{CO}_{2}$ concentrations and increased nitrogen deposition at a global scale, Funct. Ecol., 13, 439-459, 1999.

Luo, T.: Patterns of net primary productivity for Chinese major forest types and their mathematical models, Doctor of Philosophy, Chinese Academy of Sciences, Beijing, 1996.

Luo, Y., Su, B., Currie, W. S., Dukes, J. S., Finzi, A., Hartwig, U., Hungate, B., McMurtrie, R. E., Oren, R., and Parton, W. J.: Progressive nitrogen limitation of ecosystem responses to rising atmospheric carbon dioxide, Bioscience, 54, 731-739, 2004.

Mäkelä, A., Landsberg, J., Ek, A. R., Burk, T. E., Ter-Mikaelian, M., Ågren, G. I., Oliver, C. D., and Puttonen, P.: Process-based models for forest ecosystem management: current state of the art and challenges for practical implementation, Tree Physiol., 20, 289-298, 2000.

Mann, M. E., Zhang, Z., Hughes, M. K., Bradley, R. S., Miller, S. K., Rutherford, S., and Ni, F.: Proxy-based reconstructions of hemispheric and global surface temperature variations over the past two millennia, P. Natl. Acad. Sci. USA, 105, 13252-13257, 2008.

McCullagh, P.: Generalized linear models, Eur. J. Oper. Res., 16, 285-292, 1984.

McDowell, N., Pockman, W. T., Allen, C. D., Breshears, D. D., Cobb, N., Kolb, T., Plaut, J., Sperry, J., West, A., and Williams, D. G.: Mechanisms of plant survival and mortality during drought: why do some plants survive while others succumb to drought?, New Phytol., 178, 719-739, 2008.

Medvigy, D. and Moorcroft, P. R.: Predicting ecosystem dynamics at regional scales: an evaluation of a terrestrial biosphere model for the forests of northeastern North America, Philos. T. Roy. Soc. B., 367, 222-235, 2012.

Michelot, A., Simard, S., Rathgeber, C., Dufrêne, E., and Damesin, C.: Comparing the intra-annual wood formation of three European species (Fagus sylvatica, Quercus petraea and Pinus sylvestris) as related to leaf phenology and non-structural carbohydrate dynamics, Tree physiol., 32, 1033-1045, 2012.

Miller, H. G.: Carbon $\times$ nutrient interactions - the limitations to productivity, Tree physiol., 2, 373-385, 1986.

Misson, L.: MAIDEN: a model for analyzing ecosystem processes in dendroecology, Can. J. Forest Res., 34, 874-887, 2004.

Misson, L., Rathgeber, C., and Guiot, J.: Dendroecological analysis of climatic effects on Quercus petraea and Pinus halepensis radial growth using the process-based MAIDEN model. Can. J. For. Res., 34, 888-898, 2004.

Moorcroft, P., Hurtt, G., and Pacala, S. W.: A method for scaling vegetation dynamics: the ecosystem demography model (ED), Ecol. Monogr., 71, 557-586, 2001.

Moritz, M. A., Hurteau, M. D., Suding, K. N., and D'Antonio, C. M.: Bounded ranges of variation as a framework for future conservation and fire management, Ann. N. Y. Acad. Sci., 1286, 92 107, 2013

Pan, Y., Birdsey, R. A., Fang, J., Houghton, R., Kauppi, P. E., Kurz, W. A., Phillips, O. L., Shvidenko, A., Lewis, S. L., and Canadell, J. G.: A large and persistent carbon sink in the world's forests, Science, 333, 988-993, 2011.

Pierce, L. L. and Running, S. W.: Rapid estimation of coniferous forest leaf area index using a portable integrating radiometer, Ecology, 1762-1767, 1988.

Prentice, I. C., Dong, N., Gleason, S. M., Maire, V., and Wright, I. J.: Balancing the costs of carbon gain and water transport: testing a new theoretical framework for plant functional ecology, Ecol. Lett., 17, 82-91, 2014.

Rathgeber, C. B., Misson, L., Nicault, A., and Guiot, J.: Bioclimatic model of tree radial growth: application to the French Mediterranean Aleppo pine forests, Trees, 19, 162-176, 2005.

Rautiainen, M., Heiskanen, J., and Korhonen, L.: Seasonal changes in canopy leaf area index and MODIS vegetation products for a boreal forest site in central Finland, Boreal Environ. Res., 17, 72-84, 2012.

Reich, P. B., Hobbie, S. E., Lee, T., Ellsworth, D. S., West, J. B., Tilman, D., Knops, J. M., Naeem, S., and Trost, J.: Nitrogen lim- 
itation constrains sustainability of ecosystem response to $\mathrm{CO}_{2}$, Nature, 440, 922-925, 2006.

Shan, J., Tao, D., Wang, M., and Zhao, S.: Fine roots turnover in a broad-leaved Korean pine forest of Changbai mountain, Chin. J. Appl. Ecol., 4, 241-245, 1993.

Shevliakova, E., Stouffer, R. J., Malyshev, S., Krasting, J. P., Hurtt, G. C., and Pacala, S. W.: Historical warming reduced due to enhanced land carbon uptake, P. Natl. Acad. Sci. USA, 110, 1673016735, 2013.

Shinozaki, K., Yoda, K., Hozumi, K., and Kira, T.: A quantitative analysis of plant form-the pipe model theory: I. Basic analyses, Jap. J. Ecol., 14, 97-105, 1964.

Smith, B., Prentice, I. C., and Sykes, M. T.: Representation of vegetation dynamics in the modelling of terrestrial ecosystems: comparing two contrasting approaches within European climate space, Global Ecol. Biogeogr., 10, 621-637, 2001.

Stephenson, N. L., Das, A. J., Condit, R., Russo, S. E., Baker, P. J., Beckman, N. G., Coomes, D. A., Lines, E. R., Morris, W. K., and Rüger, N.: Rate of tree carbon accumulation increases continuously with tree size, Nature, 507, 90-93, doi:10.1038/nature12914, 2014.

Thomas, S. C.: Asymptotic height as a predictor of growth and allometric characteristics in Malaysian rain forest trees, Am. J. Bot., 83, 556-556, 1996.

Vaganov, E. A., Hughes, M. K., and Shashkin, A. V.: Introduction and factors influencing the seasonal growth of trees, Springer, Berlin Heidelberg, 2006.

Wang, H., Prentice, I. C., and Davis, T. W.: Biophysical constraints on gross primary production by the terrestrial biosphere, Biogeosciences Discuss., 11, 3209-3240, 2014,

http://www.biogeosciences-discuss.net/11/3209/2014/.
White, M. A., Thornton, P. E., Running, S. W., and Nemani, R. R.: Parameterization and sensitivity analysis of the BIOME-BGC terrestrial ecosystem model: net primary production controls, Earth Interact., 4, 1-85, 2000.

Wiles, G. C., D’Arrigo, R., Barclay, D., Wilson, R. S., Jarvis, S. K., Vargo, L., and Frank, D.: Surface air temperature variability reconstructed with tree rings for the Gulf of Alaska over the past 1200 years. The Holocene, 24, 198-208, 2014.

Wright, I. J., Reich, P. B., and Westoby, M.: Least-cost input mixtures of water and nitrogen for photosynthesis, Am. Nat., 161, 98-111, 2003.

Wullschleger, S. D., Tschaplinski, T. J., and Norby, R. J.: Plant water relations at elevated $\mathrm{CO}_{2}$-implications for water-limited environments, Plant Cell Environ., 25, 319-331, 2002.

Yan, X. and Zhao, J.: Establishing and validating individual-based carbon budget model FORCCHN of forest ecosystems in China, Acta Ecol. Sin., 27, 2684-2694, 2007.

Yokozawa, M. and Hara, T.: Foliage profile, size structure and stem diameter-plant height relationship in crowded plant populations, Ann. Bot.-London, 76, 271-285, 1995.

Zhang, Y., Xu, M., Chen, H., and Adams, J.: Global pattern of NPP to GPP ratio derived from MODIS data: effects of ecosystem type, geographical location and climate, Global Ecol. Biogeogr., 18, 280-290, 2009.

Zogg, G. P., Zak, D. R., Burton, A. J. and Pregitzer, K. S.: Fine root respiration in northern hardwood forests in relation to temperature and nitrogen availability, Tree Physiol., 16, 719-725, 1996. 